\title{
ORGANISASI ISLAM DI TANAH MELAYU: Ideologi dan Gerakan AI-Ittihadiyah Sebelum Era Reformasi
}

\author{
Al Rasyidin \\ Universitas Islam Negeri Sumatera Utara Medan \\ J1. Willem Iskandar Pasar V Medan Estate, Medan, Sumatera Utara, 20371 \\ e-mail: ralrasyidin@yahoo.com
}

\begin{abstract}
Islamic Organization in Malay Land: Ideology and Movements of Al-Ittihadiyah Before-Reform Era. This article examines the Al-Ittihadiyah organization in North Sumatra, focusing on its ideology, programs, and its development in a pluralistic community. This article is based on content analysys study, combining literary information and field data. This article proposes that Al-Ittihadiyah was one of the Islamic organizations established in Medan City, initiated and patronized by Malay clerics and prominent figures. As such this organisation has a very close ties with Malays, very much like the association of the Minangkabaus with Muhammadiyah and Mandailings with Al Jam'iyatul Washliyah. In addition, Al-Ittihadiyah as an organization is not affiliated with certain schools of faith and jurisprudence, but its supporters are adherents of the Ash'ariyah and Syâfi'iyah schools. Al-Ittihadiyah engages in education, da'wah and social charity. In the beginning of independence, Al-Ittihadiyah leaders joined the Masjumi Party, and later on the Unity and Development Party (PPP). It seems that this political involvement makes this organization unable to compete with Al Washliyah and Muhammadiyah.
\end{abstract}

Keywords: Islamic organization, Al-Ittihadiyah, mazhab, education, da'wah, politics, Malay 


\section{Pendahuluan}

Salah satu upaya pemerintah diHindia-Belanda untuk mengekalkan kekuasaannya di Indonesia adalah politik pecah-belah (devide et impera), baik yang dilancarkan secara terang-terangan maupun tersembunyi. Dalam dimensi kehidupan beragama, secara formal pemerintah Belanda mempropaganda politik netral terhadap agama namun secara faktual, kebijakan ini lebih tepat disebut sebagai intervensi atau campur tangan, bahkan diskriminatif. Kepada misionaris Kristen, pemerintah Belanda selalu memberikan kebebasan yang lebih luas dalam mengembangkan agama bahkan memberikan subsidi dana dalam jumlah yang besar. Sebaliknya, aktivitas dakwah misionaris Islam di daerah animisme dilarang. ${ }^{1}$ Sekolah-sekolah Kristen selalu diberi subsidi besar-besaran, sementara institusi-institusi pendidikan Islam selalu diikat dengan berbagai peraturan yang memberatkan. ${ }^{2}$ Akibatnya, tidak sedikit institusiinstitusi Islam yang berjalan apa adanya. Bahkan dengan sistem dan kurikulum tidak teratur.

Politik devide et impera yang dilancarkan Belanda ternyata merambah ke seluruh dimensi kehidupan bangsa. Adu domba antara masyarakat awam dengan kalangan bangsawan terus dilakukan. Perbedaan sekretarian dan paham keagamaan di kalangan umat Islam terus disuburkan, bahkan diperuncing. Dalam konteks ini lah dapat dilihat perseteruan antara umat Islam yang disebut sebagai Kaum Tua dan Kaum Muda ditumbuhkembangkan. ${ }^{3}$ Akibatnya, terjadilah perpecahan di kalangan umat Islam. Di satu sisi, Kaum Muda sering menuduh Kaum Tua sebagai kelompok yang jatuh ke dalam bidah, jumud, taklid dan menghambat kemajuan umat Islam. ${ }^{4}$ Sebaliknya, Kaum Tua menuduh Kaum Muda sebagai kelompok yang terlalu maju, terlalu rasional, dan ke-Barat-baratan.

Kelahiran Budi Utomo, Sarekat Islam dan sejumlah organisasi lainnya, baik yang bersifat lokal maupun nasional, kebangsaan 
maupun keagamaan menjadi sumber motivasi bagi munculnya kesadaran bangsa Indonesia untuk bersatu melawan kolonial Belanda. Momentum tersebut diperkuat lagi dengan dideklarasikannya Sumpah Pemuda tahun 1928 dan lahirnya sejumlah organisasi keislaman. Sejak saat itu, keinginan untuk bersatu dan menghimpun potensi serta kekuatan rakyat terus bergulir. Ibarat $A s h \underline{h} a ̂ b$ alKahfi yang baru terjaga dari "tidur panjangnya," bangsa Indonesia, khususnya umat Islam menyadari bahwa untuk merdeka dan maju mereka harus bersatu.

Kehadiran Al-Ittihadiyah di Sumatera Utara tahun 1935 pada dasarnya merupakan respons umat Islam di wilayah ini terhadap situasi politik dan sosial keagamaan yang berkembang di Indonesia, khususnya Sumatera Timur. Ketika itu, sebagaimana dikemukakan salah seorang mantan Ketua Umum Pengurus Besar (PB) Al-Ittihadiyah, Mahmud Abu Bakar, ${ }^{5}$ bahwa Belanda melancarkan politik pecah-belah yang melemahkan kekuatan umat Islam dan menghancurkan potensi alim ulama, karena hendak memperkuat "kukunya" untuk menjajah Indonesia buat selama-lamanya. Politik adu domba tersebut termakan oleh umat Islam, sehingga muncullah kubu atau kelompok-kelompok yang saling bermusuhan. Pada satu sisi, muncul kaum intelek yang ke-Barat-baratan yang melontarkan kata-kata yang merendahkan para ulama dan umat Islam dengan mengatakan bahwa kaum agama dan alim ulamanya adalah ortodok. Sementara itu, sebagian ulama dan penganut agama Islam menuduh orang intelek sebagai 'kaki tangan' Belanda. Pertengkaran antara dua kelompok ini semakin lama kian meruncing. ${ }^{6}$ Dalam konteks inilah, Al-Ittihadiyah hadir untuk menjembatani dan mempersatukan umat serta sebagai salah satu barisan jihad bagi kekuatan kaum Muslim. ${ }^{7}$

Secara historis, kehadiran Al-Ittihadiyah juga dilatari oleh keinginan untuk menyelenggarakan suatu sistem pendidikan Islam yang lebih teratur, lebih modern, dan terorganisir ke dalam 
suatu organisasi, khususnya sekolah-sekolah atau perguruanperguruan Islam yang belum tergabung dalam suatu organisasi tertentu. Hal ini secara eksplisit diterangkan dalam pasal 2 Statuta Al-Ittihadiyah, di mana pada ayat b dan c disebutkan bahwa maksud didirikannya Al-Ittihadiyah adalah untuk:

(b) mengoesahakan berdirinja roemah-roemah pergoeroean Islam, (c) mengatoer dan mensesoeaikan daftar peladjaran dalam roemah-roemah pergoeroean $\mathrm{AI}$ dan roemah-roemah pergoeroean yang tergaboeng dengan $\mathrm{Al}^{8}$

Dalam lapangan pendidikan Islam, Al-Ittihadiyah melihat bahwa pada era 1930-an, daftar pelajaran perguruan-perguruan Islam di Sumatera Timur masih sangat beragam. Di samping itu, guru-guru yang bertugas pada perguruan-perguruan Islam tersebut juga belum memiliki kesamaan persepsi tentang agama Islam. Karena itu, Al-Ittihadiyah didirikan untuk berusaha: (a) mempersatoekan daftar peladjaran, dan (b) mempersesoeaikan paham di antara goeroe2 terhadap soal2 jang berhoeboeng dengan agama Islam seoemoemnya.

Fakta lain yang dilihat Al-Ittihadiyah adalah kenyataan bahwa dalam pandangan masyarakat, sekolah-sekolah modern yang dibangun dan dikembangkan oleh Belanda merupakan jalur terbaik bagi mobilitas sosial secara vertikal. Perusahaanperusahaan dan kantor-kantor pemerintah hanya akan menerima dan mempekerjakan para pegawai dari tamatan sekolah-sekolah modern ini. Sementara di sisi lain, madrasah dan perguruanperguruan masih terlalu terpaku pada praktik-praktik tradisionalnya dan berorientasi murni keagamaan. Karena itu, satu-satunya lapangan pengabdian memungkinkan ditekuni para alumninya hanyalah sebagai ustaz, guru agama, mu'alim kampung, atau guruguru ngaji. Ketika Muhammadiyah, ormas Islam yang terlebih dahulu eksis di Sumatera Timur, membangun sekolah-sekolah modern seperti yang dikembangkan Belanda, minat masyarakat 
untuk menyekolahkan anaknya ke sana demikian besar. ${ }^{10} \mathrm{Di}$ sini lah tokoh-tokoh Al-Ittihadiyah melihat perlunya mereka berpartisipasi aktif dalam menyelenggarakan pendidikan Islam modern yang lebih teratur dan responsif terhadap kebutuhan masyarakat Muslim. Karena itu, ketika Al-Ittihadiyah memprogramkan aktivitasnya dalam bidang pendidikan, mereka membangun dan mengembangkan sistem pendidikan madrasah dan sekolah modern.

Artikel ini akan mengkaji perkembangan Al-Ittihadiyah sebagai organisasi Islam yang didirikan di Medan, Sumatera Utara. Secara khusus, artikel ini akan mengkaji perkembangan Al Ittihadiyah di Sumatera Utara, ideologi yang dianut organisasi, dan amal usaha yang menjadi fokus kerja organisasi. Kajian ini merupakan hasil sebuah penelitian kualitatif non-interaktif, yaitu penelitian kepustakaan. Data diperoleh dari kegiatan studi dokumen. Dokumen resmi organisasi dijadikan referensi utama dalam kajian ini. Kajian ini juga memanfaatkan data lapangan. Dokumen yang diperoleh akan ditelaah dengan menggunakan metode analisis isi.

\section{Perkembangan Al-Ittihadiyah Sebelum Reformasi}

Al-Ittihadiyah didirikan tanggal 27 Januari 1935 atau bertepatan dengan 21 Syawal 1353 Hijriah, Organisasi Islam ini dideklarasikan di gedung Zellefstandig (Yong Islamiten Bond) Jalan Sisingamangaraja, belakang Masjid Raya Medan. Ketika itu, bersama-sama dengan para ulama, cerdik pandai, dan murid-muridnya yang berjumlah 200 orang, Syekh Haji Ahmad Dahlan meresmikan berdirinya Al-Ittihadiyah ${ }^{11}$

Secara formal, maksud didirikannya Al-Ittihadiyah adalah untuk:

a. Mempertegoeh perhoeboengan silatoerahim sesama oemat Islam; b. Mengoesahakan berdirinja roemah2 pergoeroean Islam; c. Mengatoer dan mensesoeaikan daftar peladjaran 
dalam roemah2 pergoeroean $\mathrm{Al}$ dan roemah2 pergoeroean jang bergaboeng dengan AI; d. Memperloeas sjił ar dan propaganda Islam, dengan djalan melangsoengkan tabligh2, memperingati dengan oepatjara jang sepatoetnja hari2 peringatan dalam agama Islam; e.Dan lain2 oesaha jang haroes dan halal. ${ }^{12}$

Dalam Anggaran Dasar Al-Ittihadiyah pada pasal 2 dinyatakan bahwa organisasi ini berdasarkan Islam dan berlandaskan Alquran dan Sunnah Rasul. Kemudian dalam pasal 3 diterangkan pula bahwa Al-Ittihadiyah bertujuan untuk (1) mewujudkan tercapainya kualitas umat Islam yang maju dan mandiri serta dapat mengamalkan ajaran Islam li-i 'la kalimatillâh. (2) Terwujudnya cita-cita Islam dalam masyarakat dan negara Republik Indonesia yang berasaskan Pancasila dan UUD 1945 sebagai ideologi negara menuju masyarakat madani yang diridai Allah SWT. ${ }^{13}$

Pendiri Al-Ittihadiyah adalah Syekh Haji Ahmad Dahlan, seorang ulama yang berasal dari Kabupaten Langkat, Provinsi Sumatera Utara. Menurut Fuad Said, Ahmad Dahlan adalah seorang etnis Melayu. ${ }^{14}$ Pendidikan awalnya diterima dan alami dari madrasah Mahmudiyah di Kabupaten Langkat. Setelah itu, ia kemudian bertahun-tahun bermukim dan menuntut ilmu di Universitas al-Azhar, Kairo, Mesir. Sekembalinya ke tanah air, ia menekuni profesi sebagai guru agama sehingga menjadi salah seorang ulama terkemuka di masanya. Ketika studi di alAzhar, Syekh Haji Ahmad Dahlan berkenalan dengan seorang wanita Mesir yang bernama $\mathrm{Hj}$. Ummi Hanim Ali, yang kemudian dipersunting menjad istrinya. Dalam sejarah Al-Ittihadiyah, Hj. Ummi Hanim Ali juga merupakan tokoh yang turut berjasa, tidak saja dalam memberikan dukungan moril, tetapi juga materil seperti menyumbangkan uang dan emas milik pribadinya untuk mendukung pendirian dan kontinuitas Al-Ittihadiyah. ${ }^{15}$

Berbeda dengan kebanyakan organisasi Islam yang ada di tanah air, tidak lama setelah mendirikan Al-Ittihadiyah, Syekh 
Haji Ahmad Dahlan dan isterinya hijrah ke luar Sumatera Timur dan meninggalkan organisasi yang baru dibangun atau didirikannya. Tidak diketahui dengan pasti apa latar belakang hijrahnya pendiri organisasi ini. Dalam laporan pengurus AlIttihadiyah pada Muktamarnya yang pertama tahun 1941, hanya dinyatakan sebagai berikut: Toean H. A. Dahlan alm. sebagai ketoea oemoem berhoeboeng dengan beberapa hal dan keadaan, meninggalkan Soematera Timoer. ${ }^{16}$ Peristiwa kepindahan ini merupakan tantangan berat pertama yang dihadapi Al-Ittihadiyah dalam melangsungkan keberadaannya. Namun tantangan ini berhasil dihadapi oleh para tokoh pendiri lainnya dengan terus mengembangkan Al-Ittihadiyah ke berbagai daerah di Sumatera Utara.

Ketika pertama sekali didirikan, komposisi Pengurus Besar Al-Ittihadiyah terdiri atas:

Ketua Umum

: Syekh Haji Ahmad Dahlan

Ketua Muda I

: Lasimoen

Ketua Muda II

: Mohamad Nazir Nasution

Djoeroesoerat I

: Abdul Hamid Toeloes

Djoeroesoerat II

: M.M. Syarif Siregar

Bendahara

: O.K Amran, Hadji Azhari, Tasman

Mohamad Ali, Abdul Hamid, dan Ismail

Penasihat

: Syekh Hasan bin Maksum

Syekh Abdullah Afifuddin

Ketua Kehormatan

: Tengku Othman Sani Perkasa Alamsjah dan Sultan Sulaiman. ${ }^{17}$

Meskipun terdapat etnis Jawa dan Mandailing, namun jika dilihat dari komposisi etnis, para pengurus awal Al-Ittihadiyah di atas didominasi oleh etnis Melayu. Sedangkan dari sisi profesi dan kedudukan di masyarakat, para anggota Pengurus Besar Al- 
Ittihadiyah sebagaimana diterangkan di atas terdiri atas berbagai kalangan. Ketua Muda I dan Sekretaris II (djoeroesoerat 11), yakni Lasimoen dan Sjarif Siregar, keduanya merupakan pegawai Kantor Pos, Telepon, dan Telegraph (PTT). Sekretaris I, yakni Abd. Hamid, adalah seorang anggota polisi yang kemudian menjadi Komisaris Polisi di Aceh. Syekh Hasan bin Maksum ${ }^{18}$ adalah seorang ulama terkemuka di Sumatera Timur dan merupakan Imam Besar Istana Kesultanan Langkat. Demikian juga Syekh Abdullah Afifuddin, ia adalah seorang ulama dan guru besar Langkat, mantan Kepala Kantor Departemen Agama Kabupaten Deli Serdang, pernah menjabat sebagai Dekan Fakultas Syariah IAIN Ar-Raniry Cabang Medan, dan kelak hijrah serta 'menetap' di Nahdlatul Ulama (NU). Sultan Sulaiman merupakan Sultan dari Kerajaan Serdang. Sedangkan Sultan Osman al-Sani Perkasa Alamsyah merupakan putera mahkota Kerajaan Deli. Inilah profil pengurus Al-Ittihadiyah ketika pertama sekali organisasi Islam itu didirikan.

Berbeda dengan Muhammadiyah yang mayoritas etnis Minangkabau dan Al Washliyah yang mayoritas Mandailing, ${ }^{19}$ dilihat dari profil para pengurusnya dapat dikemukakan bahwa Al-Ittihadiyah merupakan organisasi Islam multi etnik dan multi profesi, meski harus diakui bahwa etnis Melayu merupakan komponen utama. ${ }^{20}$ Hal ini merupakan konsekuensi logis dari keberadaan ulama dan sultan-sultan Melayu dalam Al-Ittihadiyah. Dalam serangkaian Muktamar Al-Ittihadiyah, yaitu satu kali semasa era pra-Kemerdekaan (1941), sebelas kali di era Orde Lama (1945-1968), dan empat kali di era Orde Baru (1975-1999), pluralitas tersebut tetap dipertahankan di era pengurus yang dipilih dan terpilih dalam serangkaian muktamar tersebut tetap terdiri atas berbagai kalangan dan kelompok etnik Muslim. Begitu juga, ketika cabang-cabang AlIttihadiyah didirikan di berbagai daerah, secara etnisitas, komposisi 
pengurusnya selalu terdiri atas berbagai suku, seperti Melayu, Karo, Jawa, Banten, Mandailing, Batak, bahkan Minangkabau. ${ }^{21}$

Ketika pertama kali didirikan, untuk mempermudah penyelenggaraan aktivitas organisasi, Al-Ittihadiyah membentuk majelis-majelis yang terdiri atas Madjelis Organisatie dan Djoeroe Periksa yang dipimpin oleh Abdul Hamid Toeloes dan Sjarif Siregar; Madjelis Secretarie dan Penjiaran Oemoem; Madjelis Tarbijah; Madjelis Tabligh; Madjelis Fatwa; dan Madjelis Pers dan Propaganda. ${ }^{22}$

Selain majelis di atas, Al-Ittihadiyah juga membentuk badanbadan otonom organisasi, seperti Persatuan Pemuda Al-Ittihadiyah (PPAI) dan Persatuan Puteri Al-Ittihadiyah (PERPAI). Kedua badan otonom ini memiliki peran besar dalam menghidupkan dan menjamin kontinuitas organisasi. Pada masa Orde Lama, badan-badan otonom dalam Al-Ittihadiyah berjumlah sembilan, yaitu Persatuan Putri Al-Ittihadiyah (PERPAI); Gerakan Pemuda Al-Ittihadiyah (GERPAI); Angkatan Putri Al-Ittihadiyah; Kepanduan Al-Muhadjirin; Majelis Anak Miskin dan Yatim Al-Ittihadiyah (MAMIYAI); Zending Islam Al-Ittihadiyah; Majelis Pendidikan Pengajaran Al-Ittihadiyah; dan Majelis Tabligh Al-Ittihadiyah. ${ }^{23}$

Pada masa Orde Baru, jumlah badan otonom itu bertambah satu lagi sehingga seluruhnya berjumlah sembilan. Pertama, Persatuan Puteri (Muslimat) Al-Ittihadiyah. Kedua, Gerakan Pemuda Al-Ittihadiyah (GERPAI). Ketiga, Angkatan Putri AlIttihadiyah. Keempat, Panti Asuhan Anak Yatim MAMIYAI Al-Ittihadiyah. Kelima, Majelis Zending Islam Al-Ittihadiyah. Keenam, Majelis Pendidikan Pengajaran dan Kebudayaan AlIttihadiyah. Ketujuh, Majelis Tabligh dan Dakwah Al-Ittihadiyah. Kedelapan, Majelis Fatwa Al-Ittihadiyah. Kesembilan, Majelis Ekonomi Al-Ittihadiyah. ${ }^{24}$

Masa-masa awal eksisnya Al-Ittihadiyah, badan-badan otonom di atas, khususnya PPAI dan PERPAl sering difungsikan sebagai 
instrumen untuk unjuk kekuatan (showforce) dan menarik minat masyarakat, khususnya generasi muda, untuk memasuki AlIttihadiyah. Rapat-rapat umum dan pawai akbar selalu melibatkan PPAI dan PERPAI. Pada tahun 1935, tahun Al-Ittihadiyah didirikan, organisasi ini berhasil menghimpun 750 orang pemuda/pemudi untuk melakukan pawai keliling Kota Medan. Pawai akbar yang juga dapat dinilai sebagai showforce Al-Ittihadiyah adalah Optoch yang dilakukan pada tahun 1937. Ketika arak-arakan Al-Ittihadiyah tiba di Kerkstraat dan akan berbelok ke gang Paleisweg, mereka bertemu dengan arak-arakan ShowforceAl Washliyah yang datang dari Pekamoelia. Kedua arak-arakan ini bersatu, berjalan bersamasama menuju Istana Maimun, sehingga barisan arak-arak itu merupakan barisan besar yang terdiri atas beribu-ribu murid. ${ }^{25}$

Pada tahun 1938, dalam rangka memperingati maulid dan isra miraj, organisasi ini kembali melibatkan PPAI, PERPAl, dan murid-murid sekolah Al-Ittihadiyah dalam pawai akbar. Fakta yang sangat menarik, seluruh pawai unjuk kekuatan itu selalu berakhir di Istana Maimun dan diterima oleh Sultan Negeri Deli. Dari sini, tampak relasi yang kuat antara Al-Ittihadiyah dengan Kesultanan Melayu. Hal itu dibuktikan lagi ketika ulang tahun Kerajaan Negeri Deli pada 1938, seluruh anggota Al-Ittihadiyah dari pengurus besar hingga cabang-cabangnya serta murid-murid perguruan atau sekolahnya, melakukan optoch dan diterima oleh Sultan Deli, Putera Mahkota, Bendahara Negeri, wazir-wazir, dan orangorang besar Kerajaan Deli serta rantau jajahannya. Dalam kesempatan itu, secara tegas Sultan Deli rnenyatakan suka citanya atas kunjungankunjungan Al-Ittihadiyah ke istana Sultan. ${ }^{26}$

Suatu hal yang tampaknya merupakan 'warna khas' AlIttihadiyah dalam mengembangkan organisasinya yakni upaya merangkul dan melibatkan penguasa wilayah ke dalam organisasi Al-Ittihadiyah. Ketika pertama kali berdiri, organisasi ini berhasil mendapatkan dukungan Sultan Langkat dan merangkul Sultan 
Serdang dan putera mahkota kerajaan Deli menjadi penasihat Al-Ittihadiyah. Tidak terakomodasinya dengan baik sultan-sultan ini dalam organisasi Al Washliyah dan Muhammadiyah ${ }^{27}$ (dua organisasi Islam yang lebih dahulu berdiri di Sumatera Utara) merupakan momentum strategis bagi keberhasilan Al-Ittihadiyah dalam merangkul kedua penguasa daerah ini ke dalam organisasinya.

Melibatkan para penguasa daerah, seperti sultan dan para penghulu, ke dalam organisasi memang merupakan langkah strategis dan bisa bernilai efektif dalam mengembangkan organisasi. Keberhasilan Al-Ittihadiyah dalam mendirikan cabangnya di berbagai wilayah Karolanden, seperti Berastagi, Kabanjahe, Tiga Binanga dan Tiga Beringin serta Perboelan, umumnya dilatari oleh keterlibatan aktif sejumlah penguasa daerah. Sukses di Berastagi tidak dapat dilepaskan dari peran Sultan Koemala Boelan, yang menjabat sebagai penghulu Pekan Berastagi. Sukses di Kabanjahe, tidak bisa dilepaskan dari peran Muhammad Arif yang bergelar Maharadja, yang merupakan Hoofdmantrie der Zout en Opium Regie di Kabanjahe. Sukses pendirian cabang Tiga Beringin dan Tiga Binanga tidak juga bisa dilepaskan dari peran wakil Raja Sinembah, wakil polisi, dan penghulu Pekan Tiga Binanga dan Tiga Beringin (Randi). Kemudian di daerah Perboelan, ${ }^{28}$ keberhasilan Al-Ittihadiyah mendirikan cabang di sana tidak terlepas dari peran Gale, penghulu Pekan Perboelan, yang juga menjabat sebagai Vice Voorzitter Al-Ittihadiyah cabang Perboelan. Demikian pula, keberhasilan Al-Ittihadiyah di Kabupaten Langkat dan Binjai tidak dapat dilepaskan dari peran Lasih A. Aziz, penghulu Pekan Kwala. ${ }^{29}$

Begitu pun, tampak sebuah ironi, ketika sultan-sultan Melayu dibunuh, hartanya dirampas, dan kerajaannya dikuasai massa dalam peristiwa Revolusi Sosial tahun 1946 di Sumatera Timur, tidak tampak langkah-Iangkah nyata yang dilakukan Al-Ittihadiyah untuk membela atau mencegah peristiwa tersebut. Padahal, sama 
halnya dengan Al Washliyah, Al-Ittihadiyah telah mendapatkan dukungan penuh dari sultan-sultan Melayu dalam mendirikan dan mengembangkan organisasinya.

Sampai saat ini, belum ditemukan informasi yang dapat menjelaskan perihal sikap yang diambil Al-Ittihadiyah dalam merespons peristiwa Revolusi Sosial tahun 1946 tersebut. Apakah sikap itu dikarenakan etnis Melayu merupakan komponen utama Al-Ittihadiyah, sehingga organisasi ini memang harus' menghindar' untuk menyelamatkan diri, atau dikarenakan ketidakmampuan tokoh elit organisasi memobilitas anggota dan masa rakyat untuk mencegah dan membela sultan-sultan Melayu dari pembunuhan dan penjajahan. Adalah suatu fakta historis bahwa 'runtuhnya' kekuasaan sultansultan Melayu ternyata tidak membuat Al-Ittihadiyah mundur dan mengalami 'kematian'. Hal ini disebabkan masih adanya dukungan penguasa daerah di mana sejumlah cabang Al-Ittihadiyah seperti sejumlah penguasa di wilayah Karolanden. Di samping itu, pluralitas etnik yang sejak awal telah merintis Al-Ittihadiyah, tampaknya turut menjadi penyelamat asistensi dan kontinuitas organisasi Islam ini. Andaikata saja Al-Ittihadiyah hanya mengutamakan dukungan etnis Melayu dalam mengembangkan organisasinya, maka dapat dipastikan bahwa Revolusi Sosial yang terjadi tahun 1946 itu akan serta-merta 'mengubur' riwayat organisasi Islam ini.

Selain penguasa saluran lain yang digunakan Al-Ittihadiyah dalam mengembangkan organisasinya adalah melalui konstitusi pendidikan dan dengan memberdayakan guru-guru agama. Dalam konteks ini, Al-Ittihadiyah tampaknya berhasil membungkus dengan baik motivasi pengembangan organisasi di balik pendirian sekolah-sekolah dan perguruan Al-Ittihadiyah di berbagai daerah. Kemudian setidaknya pada periode awal, Al-Ittihadiyah juga berhasil memberdayakan guru-guru agama dalam mengembangkan organisasinya. Strategi ini bukan hal baru, sebab ketika Syekh Haji Ahmad Dahlan mendirikan Al-Ittihadiyah, ia telah memberikan 
contoh terbaik perihal pemberdayaan guru-guru agama, juga para pelajar agama. Setelah ia meninggalkan Al-Ittihadiyah, para penerusnya berhasil mengadopsi dengan baik strategi ini. Untuk sekadar contoh, sejumlah guru agama yang telah memberikan konstribusi besar bagi perkembangan Al-Ittihadiyah di antaranya: Habib Hasan (Adviseurs Al-Ittihadiyah Cabang Kabanjahe), Haji Soeleman dan Hasan Machmoed (Adviseurs Al-Ittihadiyah Cabang Tiga Binanga dan Tiga Beringin), dan Zainoeddin Arsjad Lubis (Ketua Muda Al-Ittihadiyah cabang Tebing Tinggi). ${ }^{30}$

Dilihat dari prestasi atau pencapaian, setelah Al-Ittihadiyah terbentuk, selama 6 tahun kepengurusan (1935-1941) usaha-usaha yang dilakukan para tokoh yang tergabung dalam Pengurus Besar Al-Ittihadiyah umumnya terfokus pada 4 (empat) bidang utama, yaitu: pengembangan organisasi, pengembangan syiar atau dakwah Islam, pendirian dan penggabungan sekolah dan perguruan-perguruan Islam ke dalam Al-Ittihadiyah, dan pengasuhan atau pemeliharaan anak-anak yatim. Di samping keempat bidang itu, Al-Ittihadiyah juga membentuk Majelis Simpan Pinjam serta Majelis Pers dan Propaganda yang menerbitkan majalah 'Bahtera'. Secara khusus, dalam bidang pengembangan organisasi, pada masa pra kemerdekaan Indonesia, Al-Ittihadiyah telah berhasil membentuk cabang-cabangnya di berbagai daerah Sumatera Timur, dari mulai Kota Medan, Langkat, Tanah Karo, Simalungun, Tebing Tinggi, Binjai, dan Bandar Setia, Deli Serdang. Dalam hal ini, motivasi mengembangkan syiar atau dakwah Islam dan pendirian sekolah atau madrasah, tampak selalu berada di balik pendirian cabangcabang AI-Ittihadiyah di berbagai daerah. Masih ditemukannya penganut animisme, minimnya pengetahuan agama dan rendahnya tingkat pendidikan masyarakat Muslim di Sumatera Utara menjadikan motivasi tersebut semakin rasional dan positif untuk dilakukan.

Segera setelah Pengurus Besar Al-Ittihadiyah diresmikan, para tokoh organisasi ini membentuk kepengurusan Al-Ittihadiyah 
Cabang Medan. Secara resmi, pengurus cabang Medan dibentuk pada tanggal 27 Januari 1935. Karena hari dan tanggalnya bersamaan, susunan kepengurusan Al-Ittihadiyah cabang Medan umumnya merupakan tokoh-tokoh yang tergabung dalam Pengurus Besar Al-Ittihadiyah. Pada era pra kemerdekaan, salah seorang tokoh yang menjadi Ketua Al-Ittihadiyah cabang Medan ini adalah Ibrahim Arsyad.

Setahun setelah organisasi Islam ini didirikan, tepatnya tanggal 3 Desember 1936, Al-Ittihadiyah membentuk cabangnya di Berastagi. Sebagaimana dinyatakan Ketua Panitia Conferentie Jubelleum 6 tahun Al Ittihadiyah, pendirian cabang Berastagi ini dianggap sebagai pintu pembuka jalan bagi Al-Ittihadiyah untuk mengembangkan dakwah Islam, khususnya ke daerahdaerah Karolanden dan Simalungun. ${ }^{32}$ Ada beberapa tokoh yang memainkan peran penting dalam pendirian dan pengembangan Al-Ittihadiyah cabang Berastagi. Pertama, Raden Ahmad Rahidin yang merupakan Ketua Cabang dan Wakil Pengurus Besar AlIttihadiyah untuk daerah Karolanden. Kedua, Soeran Koemala Boelan, penghulu Pekan Berastagi yang juga menjadi penasihat pengurus Al-Ittihadiyah cabang Berastagi. Ketiga, Hadji Fachroeddin, seorang dukun patah di Berastagi, yang diangkat menjadi Bendahara Al-Ittihadiyah cabang Berastagi. Keempat, Mothalib Ibrahim, seorang guru madrasah Al-Ittihadiyah Berastagi yang juga menjadi Wakil Pengurus Besar Kedua untuk daerah Karolanden. Kelima, Tuan Markoem, M. Soebandi, Sastrowikeromo, Minoen, M. Jacob, Selamat. Abdul Sjarif, dan Idris. Mereka semua menjadi anggota Pengetua Al-Ittihadiyah cabang Berastagi. ${ }^{33}$

Ketika pertama kali dibentuk, susunan kepengurusan AlIttihadiyah cabang Berastagi adalah sebagai berikut:

Ketua : Abd. Sjarif

Wakil Ketua : Markoem 
Bendahara : Abd Sjarif

Sekretaris I : Soebandi

Sekretaris II : Soekiman

Para Pembantu : Djasman, Sastrowirokrorno, Soeratmin dan Kidjan.

Penasihat : St. H. Boelan dan R. A. Rahidin

Ketua Tarbiyah : Mohd. Ali ${ }^{34}$

Dalam tahun yang sama, 1936, Al-Ittihadiyah juga mendirikan cabangnya di Kabanjahe. Pendirian cabang Kabanjahe merupakan inisiatif sebuah komite persiapan yang diketuai oleh Mohamad Arif yang bergelar Samporno Maharaja. Ia dianggap sebagai tokoh yang paling berjasa dalam pendirian Al-Ittihadiyah di wilayahnya. Untuk menindaklanjuti inisiatif komite tersebut, pada tanggal 27/28 Nopernber 1936, secara resmi dibentuklah pengurus Al-Ittihadiyah cabang Kabanjahe. Ketika itu, susunan pengurus Al-Ittihadiyah cabang Kabanjahe yang dilantik adalah sebagai berikut:

Ketua/Voorzitter : Djoemat

Sekretaris : M. Arif (Semporna Maharadja)

Komisaris : Datuk Koempoel dan Soekis

Penasihat : Habib Hasan dan Hasian Siregar

Berselang dua tahun kemudian, Al-Ittihadiyah melebarkan 'sayapnya' di daerah Karolanden dengan mendirikan cabang di Tiga Binanga dan Tiga Beringin. Sama halnya dengan Kabanjahe, pendirian Al-Ittihadiyah cabang Tiga Binanga dan Tiga Beringin. Diawali dari pembentukan panitia persiapan yang diketuai oleh Tuan Mohamad Noer. Tiga Binanga adalah pusat sebenarnya dari penduduk asli tanah Karo yang beragama Islam. ${ }^{35}$ 
Bertempat di Loads Pekan Tiga Binanga, pada hari Minggu, 27 Februari 1938, secara resmi dibentuklah pengurus Al-Ittihadiyah cabang Tiga Binanga dan Tiga Beringin. Susunan kepengurusan yang disahkan ketika itu adalah:

Ketua/Voorzitter : Randi

Wakil Ketua : Mohamad Noer

Sekertaris : Mohamad Misbah

Penningmeester : Sepaat malam

Komisaris : Oesman

Penasehat : :Hadji Soeleman, Hasan Machmud dan Ibrahim

Ketua Cabang Al-Ittihadiyah Tiga Binanga dan Tiga Beringin; Randi, adalah penghulu Pekan Tiga Beringin. Sedangkan para penasihat, yakni Hasan Machmud adalah Hoofdonderwijzer Gouv. School, sedangkan Hadji Soeleman dan Ibrahim, keduanya adalah guru agama pada sekolah Al-Ittihadiyah. Setelah terbentuk, fokus usaha yang dilakukan para pengurus Al-Ittihadiyah cabang Tiga Beringin dan Tiga Binanga adalah menyelenggarakan Majelis Tabligh, peringatan hari-hari besar keagamaan, seperti Maulid Nabi Muhammad SAW. dan isra miraj, dan mengembangkan syiar atau dakwah Islam kepada orang-orang yang belum menganut suatu agama.

Dalam tahun yang sama, 1938, Al-Ittihadiyah juga membuka cabangnya di Perboelan. Wilayah ini merupakan salah satu daerah pedalaman atau pelosok yang berada di wilayah Karolanden. Namun, antusias penduduk untuk mendirikan Al-Ittihadiyah cabang Perboelan sangat besar sekali. Meskipun termasuk daerah udik, namun lebih kurang 150 orang penduduk, di antaranya 50 orang kaum ibu, menghadiri acara pengesahan pengurus Cabang Perboelan pada tanggal 31 Juli $1938 .{ }^{36}$ 
Ketika pertama sekali didirikan, susunan anggota pengurus Al-Ittihadiyah Cabang Perboelan ini adalah sebagai berikut:

Ketua

Wakil Ketua

Sekretaris

Penningmeeste

Komisaris

Penasihat
: Gagah Sembiring

: Gale (penghulu Pekan Perboelan)

: Ali Akbar

: Bantal

: Sampak dan Rehmalam

: H. Dja'far

Setelah cabang Al-Ittihadiyah tersebar di Medan dan beberapa daerah di wilayah Karolanden, pada tahun 1940, Al-Ittihadiyah mengembangkan organisasinya ke Simalungun. Daerah ini merupakan salah satu tanah Batak di mana masih banyak terdapat orangorang yang belum memeluk suatu agama, di samping penganut agama Islam dan Kristen. Karena itu, motivasi sebenarnya pembentukan Cabang Al-Ittihadiyah di Simalungun adalah dalam rangka pengembangan dakwah dan syiar Islam.

Pada hari Jum'at tanggal 12 menjelang 13 April 1940, bertempat di madrasah Amaloeddin Javastraat, dengan dihadiri oleh 50 orang kaum bapak dan 70 orang kaum ibu, dibentuklah pengurus Cabang Al-Ittihadiyah Pematang Siantar, Simalungun. Bentukan dan pengesahan pengurus cabang Pematang Siantar dilakukan secara langsung oleh Ketua dan Sekretaris Pengurus Besar Al Ittihadiyah, yakni H. Abd. Malik dan I. M. Ruddin Sulan. Susunan kepengurusan Al-Ittihadiyah Cabang Pematang Siantar yang dilantik ketika itu adalah sebagai berikut:

Ketua I

Ketua II

Sekretaris I

Sekretaris II
: M. Atmopawiro

: Mas Abd. Rasjad

: Mara Laeot Siregar

: Said Hasan Machdar 
Bendahara : Dt. Mohd. Noer

Para Pembantu : Mas Djojopawio, Mas Soekardi, Mas Redjo

Suatu hal yang menarik, dilihat dari komposisi etnik, meskipun terdiri dari etnik yang beragam, namun susunan pengurus AlIttihadiyah Cabang Pematang Siantar tampak didominasi oleh etnis Jawa. Padahal, etnik asli Pematang Siantar adalah suku Batak, yakni Batak Simalungun. Diduga kuat, komposisi seperti itu disebabkan masih sedikitnya etnis Batak, khususnya Simalungun, yang telah memeluk agama Islam.

Setelah Al-Ittihadiyah Cabang Pematang Siantar terbentuk, dalam bulan yang sama yakni April 1940, Al-Ittihadiyah mendirikan cabangnya di Bandar Setia. Cabang ini merupakan cabang ketujuh dari seluruh cabang yang telah terbentuk sejak berdirinya AlIttihadiyah. Pengurus Al-Ittihadiyah Cabang Bandar Setia terbentuk pada tanggal 23-24 April 1940. Pembentukan dan pelantikan pengurus Cabang Al-Ittihadiyah Bandar Setia dilakukan secara langsung oleh Ketua, dan Ketua Muda Pengurus Besar Al Ittihadiyah, yaitu H. Abd. Malik dan Lasimoen, dan disaksikan oleh Komisaris Al-Ittihadiyah cabang Medan, yaitu M. Salimin. Susunan kepengurusan AI-Ittihadiyah Cabang Bandar Setia yang terbentuk ketika itu adalah sebagai berikut:

Ketua/Voorzitter : Kasan Dimangoen

Sekretaris : Mondi

Bendahara : H. Semaoen

Para Pembantu : H. Serat, Daoed, Tjokro, Sarbini, Ali

H. Achmad, Ibrahim, dan Sastro.

Masih dalam tahun 1940, Ibrahim dan Sastro membentuk cabangnya di Tebing Tinggi. Persiapan pendirian cabang Tebing Tinggi ini sebenarnya telah dimulai sejak jauh hari, yaitu sejak tahun 1938, namun baru terwujud dengan dibentuknya susunan 
Pengurus Cabang Al-Ittihadiyah Tebing Tinggi pada tanggal 24 November 1940. Bertempat di madrasah Raudathoel lslamijah dan dihadiri oleh kira-kira 120 orang, disahkanlah susunan kepengurusan Cabang Tebing Tinggi yang terdiri atas:

Ketua : Mohammad Saleh

Wakil Ketua : Zainoeddin Arsjad Lubis

Sekretaris I : Abdul Aziz

Sekretaris II $\quad$ :Soeleman Lubis, Oesman Js., dan Saleh Aziz

Bendahara : Moehamad Noer

Penasihat : Haroen

Para Pembantu : Aboe Bakar, Sanoesi, Oesman, Machmoed, Ibrahim, Abdul Rachman, Anas, Hasan Lubis.

Pembukaan cabang berikutnya terjadi pada tahun 1946. Dengan dipelopori pemuda dan pelajar madrasah dan pesantren K.H. Karim Tamin Binjai, pada tanggal 10 Januari 1946 didirikanlah Al-Ittihadiyah Cabang Kabupaten Langkat. Ketika itu, para pengurus yang dikukuhkan adalah:

Ketua Umum, I, II : : M. Arsjad Rahaman, M. Jaseh Djasad Mhd. 1ljas Amin

Sekretaris I dan II : Legiman dan M. Nurdin Saragih

Bendahara : Zainal Jakin

Para Pembantu $\quad$ : M. Kasim Arif, M. Kamil K., M. Yahya, Ali Hasan, Hasanul Arifin, Ngadi W. Ali Rahman, M. Ansjari.

Setelah tahun 1946, Cabang Al-Ittihadiyah berikutnya yang didirikan adalah Al-Ittihadiyah Cabang Kota Binjai. Dibukanya Cabang Binjai dikarenakan pada tahun 1946 status Binjai resmi sebagai Kotapraja. Melalui surat Pengurus Besar tanggal 22 Desember 1959 Nomor 317/PB/A1/59 dikukuhkanlah Al-Ittihadiyah Cabang 
Kota Binjai dengan susunan pengurus sebagai berikut:

Ketua I dan II : M. Jahja dan M. Rasjid

Sekretaris I : M. Kasim Arif

Sekretaris II : Imat Perangin-angin

Para Pembantu : M. Tahir, Ali Aman, Amat B, M. Sjarif

Ansjari

Pada tahun 1953, bertepatan dengan Muktamar Al-Ittihadiyah ke-7 di Pematang Siantar, Al-Ittihadul Wathaniyah, sebuah organisasi Islam yang didirikan oleh Syekh Haji Abd. Wahab bin Abd. Rauf Sei Lumut pada 1906, menyatakan diri bergabung ke dalam Al-Ittihadiyah. Al-Ittihadul Wathaniyah merupakan organisasi Islam yang berkedudukan di Labuhan Batu dan tersebar di berbagai wilayah seperti Negeri Lama, Sei Bamban, Tanjung Halaban, Selat Besar, Sei Palas, Sei Lumut, Sei Sanggul, Sei Berombang, dan Panipahan (dekat Bagan Siapi-api). ${ }^{37}$ Organisasi ini memiliki sejumlah lembaga pendidikan Islam yang tersebar di seluruh wilayah tersebut. Dengan tergabungnya organisasi ini, secara otomatis tersebar luaslah Al-Ittihadiyah ke Kabupaten Labuhan Batu.

Pada era praKemerdekaan dan Orde Lama, dalam hal pengembangan syiar atau dakwah Islam, Al-Ittihadiyah terus-menerus menyelenggarakan sejumlah tabligh, ceramah-ceramah lama, dan mengislamkan komunitas yang belum beragama, khususnya di daerah Langkat Hulu, Tanah Karo, Simalungun, dan Bagian Tapanuli. Kemudian dalam bidang pendidikan Islam, Al-Ittihadiyah telah mendirikan sejumlah sekolah atau perguruan Islam dan menggabungkan sekolah atau perguruan-perguruan yang belum tergabung ke dalam satu organisasi Islam mana pun. Sedangkan dalam hal pemeliharaan atau pengasuhan anak yatim, Al-Ittihadiyah berhasil membangun panti asuhan yang diberi nama panti Majelis Anak Yatim Al-Ittihadiyah yang disingkat dengan Mamiyai. 
Dalam perjalanan historis berikutnya, Al-Ittihadiyah terus berusaha memperluas wilayah pengembangan organisasi, pengembangan pendidikan, dakwah, dan pemeliharaan anak yatim. Pada masa Orde Lama, Al-Ittihadiyah mulai mengembangkan organisasinya dengan membuka perwakilan di Jakarta dengan membentuk pengurus wilayah di Bandung, Jawa Barat. Muktamar ke-12 AlIttihadiyah bahkan dilangsungkan di Bandung.

Pada tahun 1960, dilaporkan bahwa Al-Ittihadiyah telah memiliki cabang, anak cabang, dan ranting sebanyak 155 buah. Jumlah ini di luar perwakilan Al-Ittihadiyah Jakarta dan wilayah Bandung. Kemudian di awal era Orde Baru, jumlah cabang, anak cabang, ranting, dan wilayah Al-Ittihadiyah tersebut meningkat menjadi 221 buah. Begitu pun, harus diakui bahwa bila dibanding dengan organisasi Islam seperti Nahdlatul Ulama dan Muhammadiyah, pengembangan Al-Ittihadiyah ini belum berarti apa-apa, sebab hanya menyebar di wilayah Sumatera Utara.

Dalam lapangan pendidikan, sejak berdiri hingga masa Orde Baru, Al-Ittihadiyah telah berhasil membangun sejumlah sekolah, madrasah, dan satu perguruan tinggi. Ketika usia Al-Ittihadiyah mencapai seperempat abad, dilaporkan bahwa organisasi Islam ini telah memiliki 177 unit madrasah Tadjhiziyah, Ibtidaiyah, Tsanawiyah, dan Qismu 'Aly, 5 unit madrasah wajib belajar, 5 unit PGA, 21 unit Sekolah Rakyat, 3 unit SMP, dan 1 unit SMA. Jumlah tersebut terus meningkat dan pada awal masa Orde Baru, Al-Ittihadiyah telah memiliki 231 unit madrasah Ibtidaiyah, Tsanawiyah, dan Qismu 'Aly, 7 unit PGA 6 tahun, 35 unit sekolah yang terdiri dari Sekolah Rakyat, SMP, SMA, dan sebuah perguruan tinggi yang berada di jalan Gedung Arca, dekat Stadion Teladan, Medan.

Dalam lapangan dakwah dan syiar Islam, Al-Ittihadiyah tidak saja senantiasa berupaya meningkatkan kualitas dakwah melalui pelaksanaan ceramah, tabligh, dan berbagai pengajian 
agama, tetapi juga menyebarluaskan syiar Islam dengan mengislamkan para penduduk yang belum memeluk agama di berbagai daerah Sumatera Utara, seperti Tanah Karo, Langkat Hulu, Deli Hulu, dan Tapanuli Utara. ${ }^{38}$ Dari seluruh wilayah itu, Simalungun dan Karolanden menempati peringkat pertama dalam daftar usaha Al-Ittihadiyah sebagai daerah ternpat berusaha untuk perluasan syiar dan propaganda Islam. ${ }^{39}$ Prioritas untuk daerah-daerah tersebut berkaitan erat dengan kondisi daerah di mana masih banyak ditemui komunitas yang belum beragama (animisme). Di samping Majelis Tabligh, untuk mendukung pelaksanaan tugas-tugas dakwah dan syiar Islam, Al-Ittihadiyah mendirikan asrama zending Islam. Pada awalnya, zending Islam ini bergiat dalam aktivitas pengislaman, tetapi dalam perkembangan berikutnya, zending Islam ini juga melakukan aktivitas ceramah dan tabligh ke penjara dan kampungkampung. K.H. Muslich (Kepala Kantor Urusan Agama Provinsi Sumatera Utara), Zainal Arifin Abbas (Kepala Kantor Penerangan Agama Provinsi Sumatera Utara), dan K. H. Masjkur (Menteri Agama) merupakan tokoh alim ulama yang tercatat pernah menghadiri aktivitas yang dilaksanakan zending Islam Al-Ittihadiyah. ${ }^{40}$

\section{Ideologi Al-Ittihadiyah}

Al-Ittihadiyah bermakna persatuan. ${ }^{41}$ Nama ini sengaja dipilih pendiri Al-Ittihadiyah untuk merepresentasikan maksud utama yang menjadi latar belakang berdirinya organisasi ini, yaitu berupaya membangun satu perhimpunan umat Islam yang terdiri dari beberapa lapisan masyarakat Indonesia, seperti kaum bangsawan, orang kebanyakan, ulama dan pelajar, kaum intelektual dan kaum kelas menengah (intellectueeleen dan middenstanders) persatuan itu dimaksudkan untuk menjembatani kesenjangan dan perseteruan antara Kaum Muda dan Kaum Tua, antara ulama dan kelompok intelektual serta antara kaum bangsawan dan masyarakat awam. 
Inilah identitas yang merupakan ciri khas Al-Ittihadiyah ketika pertama sekali organisasi Islam ini didirikan.

Sebelum Al-Ittihadiyah didirikan, di Sumatera Utara (ketika itu masih merupakan keresidenan Sumatera Timur) telah eksis dua organisasi Islam, yaitu Al Jam’iyatul Washliyah dan Muhammadiyah. AlWashliyah disebut organisasi Kaum Tua, sedangkan Muhammadiyah adalah organisasi Kaum Muda. Memang tidak mudah mendefinisikan istilah Kaum Tua dan Kaum Muda, namun praktik keagamaan sering kali dikemukakan untuk membedakan kedua komunitas ini. Pelaksanaan qunut ketika salat subuh, men-zahir-kan niat (ushalli) ketika akan mendirikan salat, acara tahlilan atau kenduri kematian, doa berjamaah dengan mengangkat tangan merupakan contoh praktik-praktik keagamaan yang diamalkan Kaum Tua atau AlJam'iyatul Washliyah. Sedangkan Kaum Muda atau Muhammadiyah menolak praktik-praktik tersebut dan menyatakannya sebagai bidah. Persoalan furû iyah ini sering kali memperuncing relasi antara komunitas Muslim ini. Dalam kerangka inilah, Al-Ittihadiyah hadir dan mencoba menjembatani perbedaan antara Kaum Tua dengan Kaum Muda dengan maksud mempersatukan umat Islam.

Sebagaimana umumnya terjadi di wilayah Indonesia lainnya, di Sumatera Timur, perbedaan paham antara Kaum Muda dengan Kaum Tua seringkali menimbulkan gesekan-gesekan bahkan konflik berkepanjangan di tengah-tengah masyarakat. Konflik antara dua kelompok umat Islam ini seringkali berbentuk saling ejek dan saling melontarkan tuduhan kafir mengkafirkan. Begitu pun, sulit mencari referensi atau data-data tertulis berkaitan dengan upaya konkrit yang dilakukan Al-Ittihadiyah untuk menjembatani perbedaan antara dua komunitas Muslim ini. Satu-satunya statemen yang dapat ditafsirkan sebagai bukti dari sikap netral dan ingin menengahi ini adalah pernyataan bahwa 
Al-Ittihadiyah bukanlah organisasi yang berusaha mengembangkan paham-paham dan aliran baru dalam agama. Al-Ittihadiyah didirikan dengan maksud utama mempersatukan kalangan kaum Muslim. ${ }^{42}$

Dalam kenyataannya, upaya Al-Ittihadiyah untuk menyatukan Kaum Tua dan Kaum Muda tidaklah mudah. Sebagaimana dimuat dalam Sinar Deli edisi 28 Januari 1935, Al-Ittihadiyah sendiri sering digosipkan sebagai organisasi yang lebih simpati dengan azas dan gerakan baru Kaum Muda. Beberapa orang Pengurus Besar dan Pengurus Cabang Medan Al-Ittihadiyah bahkan disebut sebagai "propagandisten faham baroe." ${ }^{43}$ Sebenarnya sulit mencari bukti-bukti yang dapat menyimpulkan bahwa Al-Ittihadiyah simpati dengan azas dan gerakan Kaum Muda. Sebab, bila dilihat dari praktik-praktik keagamaannya, Al-Ittihadiyah sebenarnya memiliki banyak persamaan dengan Kaum Tua. Tampaknya, satu-satunya sebab yang membuka peluang terhadap tuduhan itu adalah aktivitas Al-Ittihadiyah dalam mendirikan atau mengembangkan sekolah yang banyak kemiripannya dengan sekolah-sekolah yang didirikan Muhammadiyah. Karenanya, tidak berbeda dengan Al Washliyah dan Nahdlatul Ulama, Al-Ittihadiyah sebenarnya termasuk organisasi Islam yang tradisional dalam soal-soal agama, tetapi cenderung bersikap modern dalam soal dunia atau lembagalembaga pendidikannya. ${ }^{44}$

Ketika dideklarasikan pada 27 Januari 1935, dalam masalah i'tiqad, Al-Ittihadiyah secara tegas menyatakan bahwa mereka berpendirian menurut i'tiqad Ahl Sunnah wa al-Jamâ'ah, yaitu $i^{\prime}$ tiqad yang sesuai dengan pendirian Imam al-Asy'arî dan alMaturidî. ${ }^{45}$ Sedangkan dalam masalah fikih, sejak awal berdirinya, secara formal Al-Ittihadiyah telah menyatakan sikap 'netralnya' menyangkut mazhab fikih. Dalam azas dan tujuan organisasi, secara eksplisit Al-Ittihadiyah menyatakan bahwa organisasi ini tidak memihak salah satu dari mazhab yang empat, tetapi menampung seluruh komunitas Muslim yang menjadi salah 
satu pengikut mazhab Syâfíî, Mâliki, ㅂanbalî, dan Hanafî. ${ }^{46}$ Begitu pun, dalam realitas empirik, ternyata Al-Ittihadiyah tampak lebih cenderung pada mazhab Syâfi'iyah. Itulah mungkin yang menyebabkan mengapa dalam perkembangan selanjutnya, pendirian Al-Ittihadiyah mengenai mazhab fikih ini akhirnya berubah. Pada Muktamar Seperempat Abad Al-Ittihadiyah yang dilangsungkan di Medan, Mahmud Abu Bakar, yang ketika itu menjabat sebagai Ketua Umum, secara tegas menyatakan bahwa Al-Ittihadiyah memakai dan sependirian dengan mazhab Syâfi'iyah. ${ }^{47}$

\section{Gerakan Al-Ittihadiyah: dari Pendidikan sampai Politik}

Menurut Fuad Said, sejak berdiri hingga tahun 1999, AlIttihadiyah telah meletakkan dasar-dasar usaha perjuangannya dalam 3 (tiga) aktivitas utama, yaitu pendidikan, dakwah, dan sosial. ${ }^{48}$ Ketiga bidang ini merupakan aktivitas 'primadona' AlIttihadiyah sepanjang perjalanan sejarahnya hingga saat ini.

\section{Bidang Pendidikan}

Perhatian Al-Ittihadiyah terhadap pendidikan dapat dikatakan demikian besar. Di antara tujuan didirikannya organisasi ini adalah untuk mengusahakan berdirinya rumah-rumah perguruan Islam dan untuk mengatur serta menyesuaikan daftar pelajaran dalam rumah-rumah perguruan Al-Ittihadiyah dan perguruan lain yang bergabung dengan Al-Ittihadiyah. ${ }^{49}$ Motivasi memajukan bangsa dan mencermati masih besarnya angka buta huruf (ketika itu mencapai angka 93\%) merupakan background dan motivasi yang berada di belakang pendirian lembaga-lembaga pendidikan Al-Ittihadiyah, baik sekolah, madrasah, maupun perguruan tinggi. ${ }^{50}$

Menurut Sayuti Noor, salah seorang tokoh ulama Al-Ittihadyah, ada tiga tujuan pendidikan Islam yang digagas Al-Ittihadiyah. Pertama, menciptakan putra/i Muslim agar mampu melaksanakan 
tugas-tugas kehidupan dunia dan akhirat. Kedua, bertujuan ' $u b u d i y a h$, yakni agar putra/i Muslim memperhambakan dirinya kepada Allah SWT. Ketiga, menjadikan putra/i Muslim menjadi manusiamanusia yang berakhlak mulia. ${ }^{51}$ Berdasarkan tujuan di atas, dalam perspektif Al-Ittihadiyah, pendidikan Islam harus mempersatukan tiga aspek utama yaitu disebut sebagai tiga serangkai, yaitu ilmu, beriman, dan beramal yang dihiasi dengan akhlak budi pekerti yang luhur. ${ }^{52}$

Untuk mencapai hal tersebut, Al-Ittihadiyah menerapkan dwi sistem dalam pelaksanaan pendidikannya dengan membangun dan mengembangkan sekaligus sistem pendidikan madrasah dan persekolahan. Untuk mengorganisir dan memajukan kedua sistem kelembagaan pendidikan tersebut, Al-Ittihadiyah membentuk badan otonom yakni Majelis Pendidikan dan Pengajaran AlIttihadiyah. Berkenaan dengan pendidikan ini, salah seorang mantan Ketua Pimpinan Pusat Al-Ittihadiyah menyatakan bahwa bagi Al-Ittihadiyah, pendidikan merupakan usaha yang sangat mendasar dalam membangun manusia Indonesia seutuhnya. Dalam perspektif Al-Ittihadiyah, konsep manusia seutuhnya itu adalah sosok manusia yang memiliki kesatuan integral antara head, heart, dan hand. ${ }^{53}$

Bagi Al-Ittihadiyah, yang dimaksud dengan head adalah pengembangan dimensi kecerdasan nalar atau akal manusia. Dalam pandangan Al-Ittihadiyah, untuk mampu melakukan suatu aktivitas atau usaha, di antara syarat utama yang diperlukan seseorang adalah kecerdasan pikiran. ${ }^{54}$ Untuk pengembangan dimensi ini, Al-Ittihadiyah mengorganisir dua jenis kurikulum pendidikan. Untuk kelembagaan madrasah, diberikan mata pelajaran ilmu pengetahuan umum sebanyak 30\%, sedangkan untuk kelembagaan sekolah sebanyak $70 \% .{ }^{55}$

Kemudian yang dimaksud heart adalah jiwa, kalbu, atau hati nurani. Pendidikan harus mengembangkan jiwa, kalbu atau 
hati nurani agar manusia memiliki akhlak dan kepribadian yang yang baik atau terpuji. Untuk mengembangkan akhlak atau kepribadian ini, diperlukan ilmu agama. Dalam konteks ini, dalam kurikulum madrasah Al-Ittihadiyah diberikan 70\% bidang studi ilmu agama, dan untuk sekolah sebanyak 30\%. ${ }^{56}$ Sedangkan hand adalah tangan, yakni dimensi yang menyangkut keterampilan jasmaniyah dalam melakukan tugas-tugas fisik-material. Menurut Al-Ittihadiyah, pendidikan Islam bukan hanya bertujuan mengembangkan kecerdasan intelektual dan kepribadian mulia, tetapi juga keterampilan jasmaniah. Persoalan ini sebenarnya telah menjadi fokus perhatian pendiri Al-Ittihadiyah, Syekh Haji Ahmad Dahlan, yang menginginkan agar murid-murid Al-Ittihadiyah antara lain harus diberi pendidikan dalam gymnastiek. ${ }^{57}$

Usaha Al-Ittihadiyah dalam pendidikan tidak hanya terfokus pada usaha pendirian sekolah atau madrasah, tetapi juga menggabungkan sekolah atau madrasah yang belum masuk ke dalam satu organisasi Islam ke dalam Al-Ittihadiyah. Sejak berdiri sampai tahun 1940, Al-Ittihadiyah telah berhasil menggabungkan enam madrasah ke dalam organisasinya, yaitu Madrasah al-Islamijah (Saintisweg), Madrasah al-Intisjarijah Soengei Kerahstrast, Madrasah al-Hoedadinijah Gloegoer, Madrasah Daoedijah Jalan Antara, Madrasah al-Sjarifijah Sidodadi, dan Madrasah al-Alijah Pertjoetweg. ${ }^{58}$

\section{Bidang Dakwah}

Secara umum, ada dua istilah yang berkembang di kalangan komunitas Al-Ittihadiyah berkaitan dengan dakwah. Pertama, dakwah disebut dengan propaganda Islam. Kedua, dakwah juga disebut dengan tabligh. Istilah propaganda Islam tampaknya merupakan term yang digunakan untuk menyebarluaskan agama Islam kepada orang-orang yang belum memeluk suatu agama. Istilah propaganda dikembangkan dari propagandisten yang juga dimaknai dengan muballighi yang diutus ke suatu tempat 
untuk menyiarkan agama Islam. ${ }^{59}$ Contoh untuk hal ini, adalah pengiriman para ustaz dan mubaligh Al-Ittihadiyah ke Tanah Karo, Simalungun dan Tapanuli Utara. Aktivitas inilah yang selalu dilakukan Al-Ittihadiyah sejak organisasi ini didirikan sampai masa kemerdekaan, Orde Lama.

Agak berbeda dengan propaganda, term tabligh tampaknya dimaknai sebagai upaya menyampaikan segala hukum-hukum Islam dengan tujuan agar umat Islam taat kepada Allah SWT. dan rasul-Nya, Muhammad SAW. Pada awalnya, aktivitas propaganda Islam disatukan dengan pers di bawah Majelis Pers dan Propaganda Islam, sedangkan tabligh memiliki majelis tersendiri yang disebut Majelis Tabligh. Namun dalam perkembangan selanjutnya, Majelis Pers dan Propaganda Islam dihapuskan. Dalam tahun 1960, badan otonom yang mengurusi dakwah berada di bawah kendali Majelis Tabligh Al-Ittihadiyah. Sedangkan untuk mendakwahkan Islam kepada orang-orang yang belum memeluk suatu agama dan mengurusi mereka, selain Majelis Tabligh, dibentuk pula Zending Islam Al-Ittihadiyah. Istilah ini tetap dipertahankan sampai masa Orde Baru. Bedanya, istilah Majelis Tabligh disatukan dengan dakwah. ${ }^{60}$

Pada masa awal berdiri sampai awal Orde Baru dakwah merupakan program unggulan Al-Ittihadiyah. Dalam konteks ini, konstribusi besar yang diberikan Al-Ittihadiyah tidak saja dalam bentuk mengislamkan masyarakat yang belum menganut suatu agama, tetapi sebagaimana dinyatakan Noer, Al-Ittihadiyah termasuk organisasi Islam yang sedikit banyaknya telah menjaga tauhid umat. Sekolah dan madrasah yang didirikan Al-Ittihadiyah juga berfungsi menjaga kelangsungan tauhid pada generasi Muslim berikutnya. ${ }^{61}$

Wilayah dakwah untuk mempropagandakan Islam kepada komunitas yang belum beragama umumnya difokuskan pada wilayah Tanah Karo, Simalungun dan Tapanuli Utara. Dalam 
pelaksanaannya, tokoh-tokoh elit dan ulama Al-Ittihadiyah turut serta secara aktif turun ke lapangan untuk melaksanakan dakwah dan mengembangkan syiar Islam.

\section{Bidang Sosial}

Dalam lapangan sosial, aktivitas Al-Ittihadiyah yang paling menonjol adalah mengasuh, memelihara, dan mendidik anakanak miskin dan yatim. Untuk keperluan ini, sejak tahun 1943, Al-Ittihadiyah telah mendirikan panti asuhan anak miskin dan yatim di Jalan Japaris Medan. Ketika terjadi revolusi kemerdekaan yang diikuti oleh agresi Belanda ke Sumatera Timur, panti asuhan anak-anak miskin dan yatim yang ada di sana diungsikan ke Pematang Siantar kemudian ke Tebing Tinggi. Kemudian pada tahun 1948, panti asuhan tersebut dipindahkan kembali ke Kota Medan bertempat di Jalan Sei Kera Nomor 199. Baru pada 5 Januari 1957, Al-Ittihadiyah berhasil menempatkan panti asuhannya secara permanen di Jalan Bromo, Kampung Tegal Sari Medan. Panti asuhan yang dinamai dengan Mamiyai ini tetap eksis dan melaksanakan kegiatannya hingga sekarang.

Dalam panti asuhan Mamiyai, anak-anak yatim tidak saja diberikan perawatan atau pemenuhan kebutuhan jasmani, tetapi juga dibina rohaniahnya yang menyangkut ilmu pengetahuan dan akhlâq al-karîmah. Al-Ittihadiyah menyediakan lembagalembaga pendidikan, seperti Sekolah Rakyat, SMP, SMA, Ibtidaiyah, Tsanawiyah, Aliyah, dan PGA bagi pembinaan kecerdasan, keterampilan, dan akhlâq al-karîmah anak-anak yatim yang berdomisili di sana.

Selain membina panti asuhan untuk menyantuni, memelihara, dan mendidik anak-anak yatim, aktivitas sosial Al-Ittihadiyah juga difokuskan pada upaya membantu para mualaf dengan membangun asrama zending Islam. Di dalam asrama zending Islam ini, para mualaf dididik dengan ajaran Islam, dengan harapan agar kelak mereka dapat memahami dan mengamalkan 
ajaran Islam dengan sebaik-baiknya.

Kegiatan lainnya di bidang sosial adalah dengan menjalin silaturahmi sesama anggota, mendidik anggota untuk hidup hemat, dan saling tolong-menolong antara sesama anggota Al-Ittihadiyah. Untuk itu, dibentuklah Majelis Simpanan dan Pertolongan (MASPAI). Majelis ini dibentuk berdasarkan keputusan rapat Pengurus Besar Al-Ittihadiyah tanggal 6 Juli 1939. Ketika mula berdiri, majelis ini diketuai oleh Ali Basjah dengan dibantu oleh Soetan Baidoerie sebagai Sekretaris dan Abdoel Hamid sebagai Bendahara. Dalam Statuta Al-Ittihadiyah, secara eksplisit dikemukakan bahwa tujuan didirikannya Majelis Simpanan dan Pertolongan ini adalah:

1. Memperkoeat perhoeboengan silatoerrahim antara pengoeroes dengan anggota dengan djalan datang mendatangi ke roemah masing-masing. 2. Mendidik anggota soepaja berhemat menjimpan oeang berdikit dikit setiap boelan. 3. Bertolong-tolongan dalam hal kematian dan kesoesahan atas angota-angota. ${ }^{62}$

\section{Bidang Kemaslahatan Umat}

Al-Ittihadiyah memandang hai ini sebagai masalah yang sangat penting. Sejak berdirinya, organisasi Islam ini senantiasa berusaha mengedepankan kemaslahatan umat Islam. Ketika konflik Kaum Tua dan Kaum Muda berlangsung, Al-Ittihadiyah menghimbau umat Islam dan anggotanya untuk saling menghormati perbedaan mazhab dan memelihara ukhuwah Islamiyah.

Dalam konteks kehidupan sosial, pada muktamarnya yang pertama, Al-Ittihadiyah secara tegas menyatakan bahwa organisasi ini akan tetap berdiri di tengah-tengah masyarakat yang terdiri dari berbagai lapisan, seperti kaum bangsawan, ulama, penuntut ilmu, intelektual, kelas menengah, dan masyarakat Muslim pada umumnya. 
Dalam konteksnya dengan penguasa, pada masa pra kemerdekaan Al-Ittihadiyah menekankan pentingnya memperhatikan dan menghormati aturan-aturan negeri serta adat kebiasaannya, baik dari pemerintahan Hindia Belanda maupun pemerintahan Zeljbestuur atau Raja-raja. ${ }^{63}$ Ketika Indonesia merdeka, untuk mencapai kemaslahatan itu, Al-Ittihadiyah senantiasa menyeru umat untuk patuh kepada Allah, Rasul, dan para pemimpin bangsa. Secara khusus, dalam hal kemaslahatan internal umat Islam, pengurus Al-Ittihadiyah pernah berpesan: cintailah perkumpulan-perkumpulan Islam seperti Muhammadiyah, Al-Djami'atul Washliyah, dan Al-Ittihadiyah. Walaupun jalannya berlainan, tetapi tujuan seluruh organisasi Islam itu serupa. Dari itu, jangan ada lagi umat Islam yang membenci perkumpulan-perkumpulan Islam yang lain. ${ }^{64}$

\section{Bidang Politik}

Al-Ittihadiyah bukanlah organisasi politik. Sikap dan pendirian ini belum pernah berubah sejak Al-Ittihadiyah didirikan sampai perkembangannya saat ini, baik pada masa kemerdekaan, Orde Lama, Orde Baru, bahkan era Reformasi saat ini. Karena bukan merupakan partai politik, Al-Ittihadiyah dengan seluruh anggotanya menyalurkan aspirasi dan cita-cita politiknya melalui partaipartai politik Islam. Ketika di tahun 1947, hubungan antara Yogyakarta dan Sumatera secara politis pulih, bersama-sama Al Jam'iyatul Washliyah, Al-Ittihadiyah menyatakan diri sebagai pendukung Masyumi. ${ }^{65}$ Dukungan ini, menurut Mahmud Abu Bakar diberikan Al-Ittihadiyah dalam rangka menghormati, menyahuti dan mengimplementasikan kesepakatan ulama dan pemuka-pemuka Islam di Yogyakarta bahwa hanya ada satu partai politik yang berasaskan Islam, yaitu Masyumi. ${ }^{66}$ Dalam Anggaran Dasar Masyumi tahun 1945, pada pasal II secara eksplisit dinyatakan bahwa Masyumi bertujuan "menegakkan kedaulatan Republik Indonesia dan agama Islam dan melaksanakan cita-cita Islam 
dalam urusan kenegaraan." ${ }^{97}$ Karena itu, dalam pandangan AlIttihadiyah, Masyumi adalah satu-satunya partai politik berasaskan Islam yang bertujuan memperjuangkan agar terlaksananya ajaran dan hukum Islam, baik dalam tataran perseorangan, masyarakat, maupun negara.$^{68}$ Sama halnya dengan sejumlah organisasi Islam lainnya, seperti Muhammadiyah, Nahdlatul Ulama, dan Al Washliyah, keberadaan Al-Ittihadiyah dalam Masyumi ada sebagai salah satu anggota istimewa yang berhak memberi nasihat atau saran kepada partai. Untuk kepentingan inilah, Al-Ittihadiyah membuka perwakilannya di Jakarta. Pada masa Orde Lama, sejumlah kader Al-Ittihadiyah duduk menjadi wakil-wakil rakyat, di antaranya Mahmud Abu Bakar (anggota DPR Daswati I Sumatera Utara), Sayuti Noor (anggota DPR kotapradja Medan), M. Saleh Peranginangin (anggota DPR kabupaten Deli Serdang). Meski demikian, harus diakui bahwa secara kuantitatif, jumlah kader Al-Ittihadiyah yang mendapat kedudukan baik sebagai pengurus partai maupun wakil rakyat di DPR, relatif 'minim' bila dibanding dengan kader-kader Al Washliyah, Muhammadiyah dan Nahdlatul Ulama.

Ketika Presiden Soekarno membubarkan Masyumi ${ }^{69}$ keanggotaan istimewa Al-Ittihadiyah pun berakhir. Dalam tataran empirik, relasi antara Al-Ittihadiyah dengan Masyumi, terutama tokohtokoh dan bekas anggota istimewa Masyumi, hanya berlangsung atas dasar ukhuwah Islamiyah. Sejak saat itu, wajah Al-Ittihadiyah di pentas politik bukan saja menurun, tetapi dapat dikatakan hampir tidak tampak lagi.

Ketika pemerintahan Orde Baru dimulai, sejumlah tokohtokoh Masyumi mencoba mendekati Soeharto untuk merestorasi partainya. Namun keinginan ini segera ditolak pemerintah Orde Baru, dan sebagai gantinya, Presiden Soeharto mengeluarkan Surat Keputusan Presiden Nomor 70 tahun 1968, yang membolehkan berdirinya Partai Muslimin Indonesia (Parmusi). Ketika itu, bersama 16 organisasi massa Islam lainnya yang bergabung 
dalam Amal Muslim Indonesia, Al-Ittihadiyah menyatakan diri sebagai pendukung Parmusi. Cita-cita dan tekad untuk melaksanakan syariat Islam dalam seluruh lapangan kehidupan, baik pada level individu, masyarakat, dan negara, tampaknya merupakan obsesi dan tujuan utama diberikannya dukungan Al-Ittihadiyah ke dalam Parmusi. Tidak mengherankan bila sejak saat itu aspirasi politik Al-Ittihadiyah beserta seluruh anggotanya disalurkan melalui Partai Muslimin Indonesia (Parmusi). ${ }^{70}$

Pada tahun 1970, ketika Presiden Soeharto mengeluarkan Surat Keputusan Presiden Nomor 77 tahun 1970, terjadi perubahan drastis dalam tubuh Partai Muslimin Indonesia. Merespons momen itu, Al-Ittihadiyah berusaha sekuat tenaga untuk memasukkan kader-kader organisasinya ke dalam pimpinan elit Parmusi. Namun, satu-satunya tokoh elit Al-Ittihadiyah yang berhasil mendapatkan posisi penting adalah H.A. Fuad Said, Ketika itu, ia mendapat mandat penuh dari Pimpinan Pusat Parmusi untuk membentuk pimpinan wilayah partai di tiga provinsi, yaitu Sumatera Utara, Aceh dan Riau.

Ketika pemerintah Orde Baru menerbitkan Undang-undang Nomor 3 tahun 1975 perihal penyederhanaan partai-partai politik peserta pemilu, satu-satunya pilihan bagi partai-partai Islam adalah memfusikan diri ke dalam satu partai. Dari proses fusi itu, lahirlah Partai Persatuan Pembangunan (PPP). Sama dengan masa sebelumnya, Al-Ittihadiyah hanya berhasil memasukkan dua kadernya ke dalam PPP. Dua kader tersebut merupakan 'wajah lama,' yaitu A. Fuad Said yang terpilih sebagai Ketua Dewan Pimpinan Wilayah PPP Sumatera Utara dan Drs. H. Imran Kadir yang berhasil menduduki posisi sebagai Ketua Departemen Koperasi/Wiraswasta PPP dan satu-satunya wakil Al-Ittihadiyah yang menjadi anggota DPR/MPR dari Fraksi PPP.

Secara umum, setelah pemilu 1977, kiprah Al-Ittihadiyah di bidang politik semakin tidak jelas. Minimnya kader-kader 
organisasi ini yang berhasil masuk sebagai pengurus inti atau elit PPP merupakan faktor utama yang menyebabkan semakin 'layunya' kiprah Al-Ittihadiyah di bidang politik. Tampaknya, Al-Ittihadiyah mengalami persoalan serius dalam kaderisasi anggota dan regenerasi kepemimpinan sehingga organisasi ini tidak berhasil memproduk kader-kader yang mumpuni di bidang politik dan menempatkannya pada pucuk pimpinan PPP. Itulah sebabnya, setelah wafatnya H. A. Fuad Said dan Drs. H. Imran Kadir, sulit menemukan kader-kader Al-Ittihadiyah dalam partai politik dan wakil rakyat di DPR dan DPRD.

\section{Penutup}

Berdasarkan kajian di atas, dapat disimpulkan tiga hal berikut. Pertama, Al Ittihadiyah didirikan oleh agamawan dari suku Melayu, bahkan mendapatkan dukungan dari Kerajaan Deli di Kota Medan. Tidak dipungkiri bahwa suku Melayu menjadi komponen utama dalam struktur pengurus Al-Ittihadiyah. Tetapi, tidak bermakna bahwa tokoh-tokoh dari suku lain tidak ada. Memang pada periode awal, tokoh dari etnis Minang cenderung menjadi pengurus Muhammadiyah, dan tokoh dari etnis Mandailing berafiliasi dengan Al Jam'iyatul Washliyah. Dalam pengembangan organisasi, Al-Ittihadiyah melibatkan pihak penguasa, sehingga roda organisasi relatif dapat berkembang.

Kedua, Al-Ittihadiyah sebagai organisasi Islam hendak menjalin persatuan umat Islam. Sebab itu, organisasi ini meletakkan Islam sebagai asas organisasi tanpa menunjukkan afiliasi organisasi dalam mazhab akidah dan fikih tertentu. Ada tuduhan bahwa Al-Ittihadiyah mendukung paham Kaum Muda, meskipun tuduhan ini ditepis oleh pengurus organisasi ini. Meskipun tidak disebutkan asas organisasi dalam bidang akidah dan fikih, para pengurusnya 
merupakan penganut mazhab Ahlussunnahwaljamaah dalam bidang akidah, dan mazhab Syâfi'iyah dalam bidang fikih.

Ketiga, Al-Ittihadiyah bergerak dalam tiga bidang utama, yaitu pendidikan, dakwah, dan sosial. Dalam bidang pendidikan, Al-Ittihadiyah mendirikan dan mengelola lembaga pendidikan terutama madrasah. Dalam bidang dakwah, Al-Ittihadiyah berupaya memperkukuh ketauhidan kaum Muslim, dan mengadakan syiar Islam di kawasan minoritas Muslim. Dalam bidang sosial, AlIttihadiyah mendirikan panti asuhan untuk memelihara anak yatim piatu dan anak fakir miskin. Dalam perjalanan sejarah, Al-Ittihadiyah sebagai organisasi dan kader-kadernya terlibat dalam politik praktis. Al-Ittihadiyah pernah menjadi anggota istimewa partai Masyumi, sedangkan kader-kadernya menjadi politisi Masyumi, Parmusi, dan PPP.

Kajian ini telah berhasil menguak ideologi, perkembangan, dan amal usaha Al-Ittihadiyah di Sumatera Utara. Tetapi, ada banyak sisi yang belum ditampilkan dalam kajian ini. Pertama, Al-Ittihadiyah telah memiliki pengurus di luar Sumatera Utara, bahkan di Jawa. Kedua, aset-aset organisasi terutama dalam bidang pendidikan mengalami kemunduran dari segi jumlah. Mayoritas madrasah tidak lagi tunduk kepada organisasi. Sebuah perguruan tinggi milik organisasi ini telah lama tutup. Kader-kader militan Al-Ittihadiyah mengalami penurunan akibat matinya roda organisasi bagian dari Al-Ittihadiyah. Kegiatan pengkaderan bahkan tidak berjalan sejak lama. Tentu saja, dua aspek ini layak menjadi kerja akademik peneliti lain. Kajian tentang Al-Ittihadiyah memang masih sangat minim dilakukan oleh peneliti.

\section{Pustaka Acuan}

Abdullah, Taufiq. Agama dan Masyarakat: Pantulan Sejarah Indonesia. Jakarta: LP3ES, 1987. 
Al Rasyidin. "Islamic Organizations in North Sumatra: The Politics of Initial Establishment and Later Development," dalam Journal of Indonesian Islam, Vol. 10, No. 1, 2016.

Arsjad, Muchlis, et al. Buku Muktamar Al-Ittihadiyah ke-XII. Bandung: Seksi publikasi Panitia Muktamar, 1968.

Azhar, Bachroem, et al. Peringatan Ulang Tahun 1/4 Abad AlIttihadiyah. Medan: Panitia Kongres ke-X Al-Ittihadiyah, 1960.

Bakar, Mahmud Abu. "Al-Ittihadiyah 1/4 Abad,” dalam Bachroem Azhar, et al. Peringatan Ulang Tahun 1/4 Abad Al-Ittihadiyah. Medan: Panitia Kongres ke-X Al-Ittihadiyah, 1960.

Bakar, Mahmud Abu. "Muktamar ke-XII Al-Ittihadiyah,” dalam Muchlis Arsjad, et al. Buku Muktamar Al-Ittihadiyah ke XII. Bandung: Seksi Publikasi Panitia Muktamar, 1968.

C.V.O Conferentie Al-Ittihadiyah. "Azas, Toejoean, Oesaha, dan Organisatie Al-Ittihadiyah,” dalam Conferentie Jubileum 6 Tahoen 1935-1941 Al-Ittihadiyah. t.t.p.: C.V.O. Conferentie Al-Ittihadiyah ke-1, 1941.

Dewan Pimpinan Pusat Al-Ittihadiyah. Pedoman Anggaran Dasar dan Anggaran Rumah Tangga Al-Ittihadiyah. Jakarta: Sekretariat DPP dan PP Muslimat Al-Ittihadiyah, 1999.

Ja'far. "Peran Al Jam“iyatul Washliyah dalam Merevitalisasi Madhhab Shafi'i di Era Kontemporer," dalam Justicia Islamica: Jurnal Kajian Hukum dan Sosial, Vol. 13, No. 1, 2016.

Ja'far. "Respons Dewan Fatwa Al Jam'iyatul Washliyah terhadap Isu Akidah dan Syariah di Era Global," dalam al-Manahij: Jurnal Kajian Hukum Islam, Vol. 10, No. 1, 2016.

Kahin, Audrey R. Pergolakan Daerah Pada Awal Kemerdekaan. Jakarta: Grafiti, 1990.

Kushimoto, Hiroko. "Islam and Modern School Education in Journal Pengasuh: Review of the Kaum Muda-Kaum Tua Dichotomy," dalam Studia Islamika, Vol. 19, No. 2, 2012. 
Noer, Deliar. Gerakan Modern Islam Indonesia 1900-1942. Jakarta: LP3ES, 1980.

Noer, Deliar. Partai Islam di Pentas Nasional. Jakarta: Grafiti Press, 1987.

Noor, Firman. "Islamic Party and Pluralism: The View and Attitude of Masyumi towards Pluralism in Politics (1945-1960)," dalam al-Jami ah: Journal of Islamic Studies, Vol. 54, No. 2, 2016.

Noor, Sayuti. "Dakwah dan Pendidikan 1slam," dalam Muktamar Al-Ittihadiyah ke-XII. Bandung: Seksi Publikasi Panitia Muktamar Al-Ittihadiyah ke-13, 1968.

Pohan, Mohd. Sjarief. "Kepentingan Propaganda Islam," dalam dalam Conferentie Jubileum 6 Tahoen 1935-1941 Al-Ittihadiyah. t.t.p.: C.V.O. Conferentie Al-Ittihadiyah ke-1, 1941.

Said, Faqih Adam. "Dari Ittihadiyah Wathaniyah ke Al-Ittihadiyah" dalam Bachroem Azhar, et al., Peringatan Ulang Tahun Abad Al-Ittihadiyah. Medan: Panitia Kongres ke-X Al-Ittihadiyah, 1960.

Said, Fuad. "Sejarah Singkat Al-Ittihadiyah dan Sambutan," dalam Pedoman Anggaran Dasar dan Anggaran Rumah Tangga Al-Ittihadiyah. Jakarta: Sekretariat DPP Al-Ittihadiyah, 1999.

Siddik, Dja'far. "Dinamika Organisasi Muhammadiyah di Sumatera Utara," dalam Journal of Contemporary Islam and Muslim Societies, Vol. 1, No. 1, 2017.

Suminta, H. Aqib. Politik Islam Hindia Belanda. Jakarta: LP3ES, 1985. 
VOL. 2 NO. 1 JANUARI-JUNI 2018

\section{Catatan Akhir:}

${ }^{1}$ Penjelasan lebih mendalam mengenai kebijakan netral pemerintah Belanda terhadap agama lihat H. Aqib Suminta, Politik Islam Hindia Belanda (Jakarta: LP3ES, 1985) dan Deliar Noer, Gerakan Modern Islam Indonesia 1900-1942 (Jakarta: LP3ES, 1980).

${ }^{2}$ Menurut Noer, Belanda memang memandang pelaksanaan pendidikan Islam sebagai ancaman terhadap kedudukan mereka. Lihat Ibid., h. 25. Bahkan ketika Belanda melipatgandakan jumlah sekolah-sekolahnya dengan dalih realisasi politik etis. Hal ini sebenarnya untuk meng-counter meluasnya pengaruh yang datang dari institusi pendidikan Islam. Lihat Taufiq Abdullah, Agama dan Masyarakat: Pantulan Sejarah Indonesia (Jakarta: LP3ES, 1987). h. 217.

${ }^{3}$ Dalam konteks ini, Noer menyatakan bahwa sikap pemerintah Belanda terhadap kalangan tradisi (Kaum Tua) dibanding dengan sikapnya terhadap kalangan modern (Kaum Muda) lebih lunak, karena di kalangan tradisi lebih banyak memperhatikan agama dalam arti sempit dan kurang atau tidak berwarna politik sama sekali. Politik pecah belah (devide et impera) Belanda memang menghendaki pilih kasih terhadap berbagai golongan. Belanda lebih menyukai kalangan tradisi karena mereka dianggap lebih bisa menerima status quo. Lihat Noer, Gerakan Modern Islam Indonesia, h. 336. Lebih lanjut tentang Kaum Muda dan Kaum Tua, lihat Hiroko Kushimoto, "Islam and Modern School Education in Journal Pengasuh: Review of the Kaum MudaKaum Tua Dichotomy,” dalam Studia Islamika, Vol. 19, No. 2, 2012, pp. 207-250.

${ }^{4}$ Noer, Gerakan Modern Islam Indonesia, h. 323.

${ }^{5} \mathrm{H}$. Abu Bakar adalah salah satu seorang mantan Ketua Umum Pengurus Besar Al-Ittihadiyah yang telah terpilih menjadi Ketua Umum sejak Kongres II AlIttihadiyah di Tebing Tinggi pada tahun 1945. Ia lahir di Tebing Tinggi, Deli tahun 1915. Ia merupakan salah seorang alumni madrasah Al-Ittihadiyah pimpinan Tuan Syekh H. Abdul Malik Sukardja dan pernah bermukim di Makkah selama 4 tahun dan belajar pada Madrasah Saulatiah. Pernah menjabat sebagai Ketua III BKS ulama Militer Daswati I Sumatera Utara, anggota Dewan Pimpinan Masjumi wilayah Sumatera Utara, dan anggota DPRD provinsi Sumatera Utara. Lihat Bachroem Azhar et al., Peringatan Ulang Tahun 1/4 Abad Al-Ittihadiyah (Medan: Panitia Kongres ke X AlIttihadiyah, 1960), h. 66.

${ }^{6}$ Mahmud Abu Bakar, "Al-Ittihadiyah 1/4 Abad," dalam Bachroem Azhar et al., Peringatan Ulang Tahun 1/4 Abad Al-Ittihadiyah(Medan: Panitia Kongres ke-X Al-Ittihadiyah, 1960), h. 15.

${ }^{7}$ Mahmud Abu Bakar, "Muktamar ke-XII Al-Ittihadiyah," dalam Muchlis Arsjad et al., Buku Muktamar Al-Ittihadiyah ke XII(Bandung: Seksi publikasi Panitia Muktamar, 1968), h. 19.

${ }^{8}$ Lihat C.V.O Conferentie Al-Ittihadiyah, “Azas, Toejoean, Oesaha, dan Organisatie Al-Ittihadiyah," dalam Conferentie Jubileum 6 Tahoen 1935-1941 Al-Ittihadiyah (t.t.p.: C.V.O. Conferentie Al-Ittihadiyah ke-1, 1941), h. 16.

${ }^{9}$ Ibid., h. 51. 
${ }^{10}$ Dja'far Siddik, “Dinamika Organisasi Muhammadiyah di Sumatera Utara," dalam Journal of Contemporary Islam and Muslim Societies, Vol. 1, No. 1, 2017, h. 1-40.

${ }^{11}$ Ibid., h. 27, dan Muchlis Arsjad et al., Buku Muktamar Al-Ittihadiyah ke XII, h. 18.

${ }^{12}$ Ibid. Lihat juga Azhar et al., Peringatan Ulang Tahun 1/4 Abad Al-Ittihadiyah, h. 15 .

${ }^{13}$ Dewan Pimpinan Pusat Al-Ittihadiyah, Pedoman Anggaran Dasar dan Anggaran Rumah Tangga Al-Ittihadiyah (Jakarta: Sekretariat DPP dan PP Muslimat Al-Ittihadiyah, 1999), h. 68

${ }^{14}$ Fuad Said, "Sejarah Singkat Al-Ittihadiyah dan Sambutan," dalam Pedoman Anggaran Dasar dan Anggaran Rumah Tangga Al-Ittihadiyah (Jakarta: Sekretariat DPP Al-Ittihadiyah, 1999), h. 56.

${ }^{15}$ Ibid., h. 56.

${ }^{16}$ Lihat C.V.O. Conferentie, Conferentie Jubileum 6 Tahoen 1935-1941, h. 31.

${ }^{17}$ Ibid., h. 28; Muchlis Arsjad et al., Buku Muktamar Al-Ittihadiyah ke XII, dan Fuad Said, "Sejarah Singkat Al-Ittihadiyah dan Sambutan,”h. 56.

${ }^{18} \mathrm{Ja}$ 'far, "Tarekat dan Gerakan Sosial Keagamaan Shaykh Hasan Maksum," dalam Teosofi: Jurnal Tasawuf dan Pemikiran Islam, Vol. 5, No. 2, 2015.

${ }^{19}$ Tentang Al Washliyah lihat Ja'far, "Peran Al Jam iyatul Washliyah dalam Merevitalisasi Madhhab Shafi'i di Era Kontemporer," dalam Justicia Islamica: Jurnal Kajian Hukum dan Sosial, Vol. 13, No. 1, 2016, h. 1-29; Ja'far, "Respons Dewan Fatwa Al Jam'iyatul Washliyah terhadap Isu Akidah dan Syariah di Era Global," dalam al-Manahij: Jurnal Kajian Hukum Islam, Vol. 10, No. 1, 2016.

${ }^{20} \mathrm{Al}$ Rasyidin, "Islamic Organizations in North Sumatra: The Politics of Initial Establishment and Later Development," dalam Journal of Indonesian Islam, Vol. 10, No. 1, 2016, pp. 64-88.

${ }^{21}$ Pada awal berdirinya, tidak ada seorang pun etnis Minang yang ada atau memasuki Al-Ittihadiyah. Hal ini disebabkan, orang Minang dulunya adalah para simpatisan dan anggota Muhammadiyah, sebuah organisasi Islam yang berskala nasional dan telah lebih dahulu berkembang di Medan. Namun dalam perkembangan berikutnya, di cabangcabang Al-Ittihadiyah, ternyata orang Minang juga memasuki Al-Ittihadiyah, meskipun ke dalam jumlah yang besar.

${ }^{22}$ C.V.O. Conferentie, Conferentie Jubileum 6 Tahoen 1935-1941, h. 1.22.

${ }^{23}$ Azhar et al., Peringatan Ulang Tahun Conferentie Jubileum 6 Tahoen 19351941 Abad Al-Ittihadiyah, h. 16

${ }^{24}$ Arsjad et al., Buku Muktamar Al-Ittihadiyah ke XII, h. 20.

${ }^{25}$ C.V.O. Conferentie, Conferentie Jubileum 6 Tahoen 1935-1941, h. 53.

${ }^{26}$ Ibid., h. 55.

${ }^{27}$ Tidak diakomodasinya penguasa kesultanan Melayu, baik dalam Al Jam 'iyatul Washliyah maupun Muhammadiyah, dikarenakan bangsawan Melayu dipandang 'bersahabat' dengan pemerintah kolonial Belanda, bahkan dianggap sebagai 'antek-antek' Belanda. Persahabatan dan kerjasama tersebut bahkan terus berlangsung sampai agresi Belanda 
tahun 1946. Menurut Langenberg, bangsawan Melayu, sebagian besar raja-raja Simalungun, beberapa kepala suku Karo, dan kebanyakan tokoh-tokoh Cina merupakan aliansi anti Republik Indonesia yang ikut mempersiapkan berdirinya Negara Sumatera Timur. Lihat dalam Audrey R. Kahin, Pergolakan Daerah Pada Awal Kemerdekaan (Jakarta: Grafiti, 1990), h. 139-140.

${ }^{28}$ Lihat C.V.O. Conferentie, Conferentie Jubileum 6 Tahoen 1935-1941, h. 32-43.

${ }^{29}$ Lihat Azhar et al., Peringatan Ulang Tahun 1/4 Abad Al-Ittihadiyah, h. 46.

${ }^{30}$ Lihat C.V.O. Conferentie, Conferentie Jubileum 6 Tahoen 1935-1941, h. 32-43.

${ }^{31}$ Setelah terbit 10 nomor, akhirnya penerbitan majalah Bahtera dihentikan dikarenakan kekurangan dana. Lihat Ibid., h. 68.

${ }^{32}$ Ibid., h. 32.

${ }^{33}$ Ibid., h. 33.

${ }^{34}$ Ibid., h. 33.

${ }^{35}$ Ibid., h. 35.

${ }^{36}$ Ibid., h. 42.

${ }^{37}$ Faqih Adam Said, "Dari Ittihadiyah Wathaniyah ke Al-Ittihadiyah," dalam Bachroem Azhar et al., Peringatan Ulang Tahun 1/4 Abad Al-Ittihadiyah (Medan: Panitia Kongres ke X Al-Ittihadiyah, 1960), h. 52-53.

${ }^{38}$ Lihat Azhar et al., Peringatan Ulang Tahun 1/4 Abad Al-Ittihadiyah, h. 19.

${ }^{39}$ C.V.O. Conferentie, Conferentie Jubileum 6 Tahoen 1935-1941, h. 19.

${ }^{40}$ Azhar et al., Peringatan Ulang Tahun 1/4 Abad Al-Ittihadiyah, h. 19.

${ }^{41}$ C.V.O. Conferentie, Conferentie Jubileum 6 Tahoen 1935-1941, h. 16.

${ }^{42}$ Ibid., h. 16. Menurut Noer, sekitar tahun 1935, kedua kelompok tersebut mulai berseru pada perlunya persatuan, dengan mengemukakan perlunya toleransi serta tekanan bahwa mereka tergolong sama saudara umat Muhammad. Banyak di antara keduanya yang mengadakan perjalanan propaganda bersama untuk kepentingan Islam dan sebagai cermin dari pendekatan bersatu yang mereka lakukan. Lihat Deliar Noer, Gerakan Modern Islam, h. 337.

${ }^{43}$ C.V.O. Conferentie, Conferentie Jubileum 6 Tahoen 1935-1941, h. 31.

${ }^{44}$ Deliar Noer, Partai Islam di Pentas Nasional (Jakarta: Grafiti Pers, 1987), h. 49.

${ }^{45}$ Azhar et al., Peringatan Ulang Tahun 1/4 Abad Al-Ittihadiyah, h. 5.

${ }^{46}$ C.V.O. Conferentie, Conferentie Jubileum 6 Tahoen 1935-1941, h. 16.

${ }^{47}$ Azhar et al., Peringatan Ulang Tahun 1/4 Abad Al-Ittihadiyah, h. 16.

${ }^{48}$ Fuad Said. "Sejarah Singkat Al-lttihadiyah dan Sambutan,” h. 58.

${ }^{49}$ C.V.O. Conferentie, Conferentie Jubileum 6 Tahoen 1935-1941, h. 17.

${ }^{50}$ Arsjad, "Menindjau ke Pergoeroean Islam," dalam C.V.O. Conferentie Conferentie Jubileum 6 Tahoen 1935-1941, h 82.

${ }^{51}$ Sayuti Noor, "Dakwah dan Pendidikan 1slam," dalam Muktamar Al-Ittihadiyah ke XII (Bandung: Seksi Publikasi Panitia Muktamar Al-Ittihadiyah ke-13, 1968), h. 52-53.

${ }^{52}$ Ibid., h. 53. 
${ }^{53}$ Said, "Sejarah Singkat Al-Ittihadiyah dan Sambutan," h. 58.

${ }^{54}$ C.V.O. Conferentie, Conferentie Jubileum 6 Tahoen 1935-1941, h. 21.

${ }^{55}$ Azhar et al., Peringatan Ulang Tahun 1/4 Abad Al-Ittihadiyah, h. 18.

${ }^{56}$ Ibid., h. 18.

${ }^{57}$ C.V.O. Conferentie, Conferentie Jubileum 6 Tahoen 1935-1941, h. 53.

${ }^{58}$ Ibid., h. 52.

${ }^{59}$ Mohd. Sjarief Pohan, "Kepentingan Propaganda Islam," dalam C.V.O. Conferentie, Conferentie Jubileum 6 Tahoen 1935-1941, h. 89.

${ }^{60}$ Azhar, et al., Peringatan Ulang Tahun 1/4 Abad Al-Ittihadiyah, h. 16.

${ }^{61}$ Noer, Partai Islam, h. 426.

${ }^{62}$ C.V.O. Conferentie, Conferentie Jubileum 6 Tahoen 1935-1941, h. 72.

${ }^{63}$ Ibid., h. 20.

${ }^{64}$ Ibid., h. 64.

${ }^{65}$ Noer, Partai Islam, h. 49;

${ }^{66}$ Azhar, et al., Peringatan Ulang Tahun 1/4 Abad Al-Ittihadiyah, h. 20.

${ }^{67}$ Noer, Partai Islam, h. 118.

${ }^{68}$ Azhar, et al., Peringatan Ulang Tahun 1/4 Abad Al-Ittihadiyah, h. 20.

${ }^{69}$ Firman Noor, "Islamic Party and Pluralism: the View and Attitude of Masyumi towards Pluralism in Politics (1945-1960)," dalam al-Jami’ah: Journal of Islamic Studies, Vol. 54, No. 2, 2016, pp. 273-310.

${ }^{70}$ Said, "Sejarah Singkat Al-lttihadiyah dan Sambutan," h. 6. 